\title{
The OECD Inclusive Framework
}

\begin{abstract}
This article considers the various issues and implications raised by the OECD's Inclusive Framework and how this affects both OECD member countries and non-member states.
\end{abstract}

\section{Introduction}

The Inclusive Framework is a new global tax governance network created by the OECD to facilitate implementation of its signature tax coordination project, i.e. the OECD/G20 Base Erosion and Profit Shifting (BEPS) initiative. The OECD intends the Inclusive Framework to engage participating states in "an inclusive dialogue on an equal footing to directly shape standard setting and monitoring processes". ${ }^{1}$ This implies, without expressly defining, a vision of international tax policy negotiation in which all participating states have a meaningful say in decision-making that affects them. If this is the goal, achieving an equal footing will require a significant institutional commitment to overcome the vast differences in resources, capacity and relative bargaining strengths of the participating states. If, however, this ideal does not broadly describe the OECD's aim, the language of equal footing requires more explanation to avoid the risk of being dismissed as mere rhetoric

This article argues that as defined, inclusivity on an equal footing is an important goal for international tax policymaking, but key institutional governance issues need to be addressed in order to determine whether the OECD can

Professor and H. Heward Stikeman Chair in the Law of Taxation, McGill University Faculty of Law. The author can be contacted at allison.christians@mcgill.ca.

* Assistant Professor in Philosophy, Leiden University, the Netherlands. The author can be contacted at l.c.j.van. apeldoorn@phil.leidenuniv.nl.

This article was written while the latter held an O'Brien Fellowship at the McGill University Centre for Human Rights and Legal Pluralism, the support of which he gratefully acknowledges.

A draft of this article was presented at an interdisciplinary con ference "International Tax Policy in a Disruptive Environment" organized by the Max Planck Institute for Tax Law and Public Finance in Munich on 14-15 December 2017. The conference was supported by The Harvard Fund for Tax and Fiscal Research and The H. Heward Stikeman Chair in the Law of Taxation at the McGill University Faculty of Law. For helpful comments on an early draft, the authors thank Montano Cabezas, Kuzivakwashe Charamba, Maikel Evers, Pascal St. Amans, Joseph Stead, Stephen Shay, Wolfgang Schön and the participants of the conference.

1. OECD, All interested countries and jurisdictions to be invited to join global effortsled by the OECD and G20 to lose international taxloopholes(OECD 2016), available at www.oecd.org/ctp/all-interested-countries-and-jurisdictions-to-be-invited-to-join-global-efforts-led-by-the-oecdand-g20-to-close-international-tax-loopholes.htm. The OECD further promises that its BEPS initiative measures will protect the tax bases of participant countries and that participation in the Inclusive Framework will allow countries to access "capacity building support" for BEPS implementation. Id. achieve this goal with the Inclusive Framework. Section 2. lays out a normative defence of inclusivity on an equal footing as a worthy goal for international tax policy negotiation. Section 3. surveys the OECD's development of various inclusive tax forums culminating in the Inclusive Framework and argues that institutional obscurity makes it difficult to determine the criteria or judge the outcome of inclusivity on an equal footing. Section 4 . examines some of the challenges that will likely arise in defining and assessing inclusivity in the Inclusive Framework. In section 5., the article concludes that because the Inclusive Framework will be a key location for international tax policymaking for the foreseeable future, what the OECD means by inclusivity on an equal footing requires more explicit definition than has been revealed to date.

\section{The Value of Inclusivity}

The Inclusive Framework is a global tax body expressly convened for the purpose of facilitating global implementation by all willing nations of the OECD's signature tax coordination project on base erosion and profit shifting, or BEPS. BEPS is a broad and multifaceted initiative designed to address the major international tax issues of our time. ${ }^{2}$ The Inclusive Framework was created to solve a practical problem, namely, how to create a means by which all interested countries can work in a unified way toward a common goal that has been developed within an organization of limited membership. ${ }^{3}$ The OECD announced the Inclusive Framework as the solution in 2015, assuring all those who joined that they would participate in its activities on an equal footing. ${ }^{4}$

2. For a detailed explanation of the BEPS projects including the role of the Inclusive Framework in facilitating its implementation, see A. Christians \& S. Shay, General Report, in Assessing BEPS: origins, standards, and responses, International Fiscal Association (IFA) Cahier de droit international vol. 102A (2017), Online Books IBFD.

3. The OECD's nature as a membership organization with a limited and rigorous accession policy raises the question of whether or not it is able to balance its responsibility to advance the interests of its members with responding to the specific needs and interests of non-member countries. For a detailed look at the political ramifications of the OECD accession process, see C.L. Davis, More Than Just a Rich Country Club: Membership Conditionality and Institutional Reform in the OECD, Working Paper, Princeton U. (26 June 2016), available at www.princeton.edu/ cldavis/files/Davis_OECDmembership_2016.pdf.

4. The term 'equal-footing", in conjunction with 'inclusivity', is mentioned consistently in invitations to join the Inclusive Framework and to describe the methodology of the work done by the BEPS Project post 2015 when the Inclusive Framework was introduced. For example, the first progress report on the Inclusive Framework in July 2017 mentions the term eight times to emphasize the nature of how countries are working together, but does not explicitly define the term. See OECD, Progress Report (OECD 2017) (explaining that "The establishment of the Inclusive Framework on BEPS has marked a seminal moment in the global governance of international tax issues ... 100 countries and jurisdictions having expressed a high-level commitment to work together, on an equal footing" and that "[a]ll members of the Inclusive Framework participate on an equal footing in the decision-making body, as well as in the technical working groups"). 
The OECD has been silent regarding the reasons for pursuing equal participation of non-member countries in its tax policy work, and there is no official explanation of what is meant by having an equal footing. The effort to involve non-members implicitly appears to respond to charges that the organization cannot claim legitimacy as a "global tax policy leader" while maintaining processes that are both exclusive and opaque. ${ }^{5}$ These efforts also accord with inclusivity goals laid out in the Sustainable Development Goals and the Addis Ababa Action Agenda. ${ }^{6}$

The goal of inclusivity in governance, broadly stated, is normatively supported for both instrumental and procedural reasons. ${ }^{7}$ Instrumentally, equal participation should enable all parties, including poorer and more vulnerable countries, to effectively advance the interests of their citizens in international negotiations on issues that affect them. Equal participation ideally contributes to a more equitable distribution of the benefits and burdens of international cooperation. Procedurally, equal participation may contribute to the fairness and legitimacy of decision-making, and responds to the ideal of the parties being worthy of recognition as equal, self-determining members in the society of states. Both of these arguments can be advanced on the basis of a wide range of philosophical theories in the literature on global distributive justice. ${ }^{8}$

The instrumental reason is most salient for "cosmopolitan" or "globalist" theories, which maintain that principles of egalitarian distributive justice are global in scope. ${ }^{9}$ Such accounts of justice are generally concerned with reduc-

5. Such charges form the basis for calls for a change of venue for international tax policymaking, either to the United Nations or to an independent world tax organization. The Inclusive Framework was announced soon after OECD members rejected one such call, which was raised at the United Nations Third Annual Conference on Financing For Development in Addis Ababa on 27 July 2015. See www.un.org/esa/ffd/ffd3/. The Tax Justice Network (TJN) continues to be a major advocate for a non-OECD international tax policymaking venue. See, for example, Nick Shaxson, Ecuador's president calls for global tax body, TJN (28 Sept. 2016) (describing the events at Addis and quoting an observer as stating that "After three days of bullying, developing countries were finally run over. The consequence of the Addis Ababa outcome is that more than 100 developing countries will remain excluded from decision making on global tax standards."). See also eur. network on debt \& dev. (eurodad), An Intergovernmental UN Tax Body - why we need it and how we can get it (29 August 2016), available at www.eurodad.org/Intergovernmental-Tax-Body-Why-We-Need-It (stating that "the international tax system is managed by a club of rich countries as 'rule makers', with developing countries excluded from decision making as mere 'rule-takers'. What is need to remedy the weaknesses of this system is an intergovernmental, universal, adequately resourced global tax body, backed by technical expertise and established under the auspices of the UN.").

6. Addis Ababa Action Agenda of the Third International Conference on Financing for Development (UN 2015), available at https://sustainabledevelopment.un.org/content/documents/2051AAAA_Outcome. pdf.

7. S. Caney, Cosmopolitan Justice and Institutional Design: An Egalitarian Liberal Conception of Global Governance, 32 Social Theory \& Prac. p. 745 (2006), p. 745.

8. This is not to say that these arguments would be universally endorsed For a skeptical view, see, for example, T. Nagel, The Problem of Global Justice, 33 Phil. \& Pub. Affairs p. 113 (2005). For critical responses, see A.J. Julius Nagel's Atlas, 34 Phil. \& Pub. Affairs p. 1 (2006) and J. Cohen \& C. Sabel, Extra Rempublicam Nulla Justitia? 34 Phil. \& Pub. Affairs p. 147 (2006).

9. For example, C. Beitz, Political Theory and International Relations (Princeton U. Press 1999); G. Brock, Global Justice: A Cosmopolitan Account (Oxford U. Press 2009); S. Caney, Cosmopolitanism and Justice, in Contemporary Debates in Political Philosophy (T. Christiano ing comparative global inequality between individuals. While they propose conflicting accounts of how much inequality is acceptable, as well as the appropriate metric to measure it (for instance, in terms of individual opportunity or monetary wealth), all reject as morally indefensible the extreme global inequality that we witness today. From this perspective, participating in global governance institutions could be an instrumental (if perhaps second-best) means of securing a just distribution of advantages between individuals. If successful, the inclusion on an equal footing of low-income countries in the Inclusive Framework might meet global justice demands by ensuring that further reforms of the international taxation regime contribute to the reduction of global inequality, or at least that the citizens of the most vulnerable countries do not fall ever further behind.

The procedural reason is most compelling from the perspective of more conservative "statist" theories of global justice, such as those of Rawls (1999) and Miller (2007). ${ }^{10}$ Rawls and Miller defend, in different ways, the importance of securing conditions of effective national self-determination. Rawls denies that justice requires the satisfaction of some global principle of egalitarian justice. Rather, he posits that justice demands the protection of conditions in which countries can effectively shape their domestic affairs in accordance with the wishes of their populations. Countries can exercise this capacity only when they are able to advance their interests in relation to other states. Similarly, Miller maintains that national self-determination requires "fair terms of cooperation between societies, in particular terms of cooperation that allow weaker and less developed societies the opportunity to develop along paths of their own choosing". ${ }^{11}$ Establishing fair terms of cooperation, based on decision-making on an equal footing, therefore promotes national self-determination. ${ }^{12}$

The OECD's promise of an equal footing for non-member countries thus advances an idea about how national self-determination and global distributive justice could be advanced under its supervision. In order to gauge whether this promise is fulfilled, it is necessary to understand how the OECD envisions what participation on an equal footing in the Inclusive Framework means in practice. An examination of the steps that the OECD has taken to open its tax processes to non-member countries provides some clues but also demonstrates that the OECD needs to be more transparent about its governance aims and its processes for meeting them.

\& J. Christman eds., Wiley-Blackwell 2009); and D. Moellendorf, Global Inequality Matters (Palgrave 2009).

10. J. Rawls, The Law of Peoples (Harvard University Press 1999) and D. Miller, National Responsibility and Global Justice (Oxford U. Press 2007).

11. Miller supra n. 10 at p. 267.

12. It is an open question whether Rawls, supra n. 10 and Miller, supra n. 10 particular accounts of national self-determination are sufficiently robust. For a critical discussion, see A. Banai, Freedom Beyond the Threshold: Self-determination, Sovereignty, and Global Justice, 8 Ethics \& Global Pol. p. 21 (2015). 


\section{Origins of Equal Footing: The Road to the Inclusive Framework}

The OECD is a notoriously difficult institution to study. For observers of the OECD's tax policy work, the principle challenge lies in locating clear statements of institutional decisions, especially about governance structures and processes. Some inferences may be drawn from the nature of the OECD as a member organization and from its historical role in managing the geo-politics of the international tax law order. Others may be drawn by examining the chronological development of forums leading up to and including the creation of the Inclusive Framework. Each of these is discussed in turn.

\subsection{The significance of membership}

Seeking equal participation of member and non-member states appears to be an uncharacteristic mandate for a membership organization like the OECD. A main goal articulated in the OECD's constituting document signed in 1960, and reiterated since then across OECD reports and other statements, is to promote growth, employment and economic expansion of its member countries. ${ }^{13}$ However, this goal is typically accompanied by two others, namely, to promote economic expansion of non-member developing countries and to contribute to the expansion of world trade. ${ }^{14}$ The OECD's institutional structure guides its pursuit of these goals.

In regards to taxation, OECD members generally develop policy norms through collaborative consensus-building. ${ }^{15}$ Tax policy develops in three intersecting networks within the OECD: the OECD Council, the Centre for Tax Policy and Administration (CTPA) and the Committee on Fiscal Affairs (CFA). ${ }^{16}$ The Council, which is the OECD's agenda setting and decision-making body, consists of high-level officials of member countries, plus one member of the

13. Convention on the Organisation for Economic Co-operation and Development, Paris, 14 December 1960, art. 1 (stating that the OECD shall "promote policies designed: (a) to achieve the highest sustainable economic growth and employment and a rising standard of living in Member countries, while maintaining financial stability, and thus to contribute to the development of the world economy; (b) to contribute to sound economic expansion in Member as well as non-member countries in the process of economic development; and (c) to contribute to the expansion of world trade on a multilateral, non-discriminatory basis in accordance with international obligations.").

14. Id

15. The OECD took the lead as the main forum for transnational tax collaboration beginning in the early 1960 s and it is a critical focal point for exploring how global tax policy currently develops; while the United Nations also has a permanent tax policy committee, the OECD has long dominated the tax policy landscape in terms of resources and personnel. See A. Christians, Networks, Norms, and National Tax Policy, 9 Wash. U. Glob. Stud. L. Rev 1 (2010) and P. Carroll \& A. Kellow, The OECD: A Study of Organisational Adaptation (Edward Elgar 2011); see also OECD, Platform for Collaboration on Tax (OECD), available at www.oecd.org/tax/platform-for-collaboration-on-tax.htm (articulating a multi-institutional confirmation that the OECD should continue its role in leading international tax policy through networking and consensus building).

16. The organizing document is the Convention on the Organisation for Economic Co-operation and Development, Signed December 14, 1960 in Paris, which "reconstituted" the former Organisation for European Economic Co-operation, Convention on the Organization for Economic Co-operation and Development, 14 December 1960.
European Union. ${ }^{17}$ The Secretariat, the CTPA, the CFA and all sub-committees and committees are populated from OECD member countries, with non-members invited as observers from time to time. ${ }^{18}$ OECD staff, from OECD member countries, facilitate "countless little technical committees" that collectively construct a pluralistic legal order. ${ }^{19}$ Legal scholars observe that these networks and processes have made the OECD a de facto world tax organization for many years. ${ }^{20}$

When the OECD expanded its work programme to include non-member countries in the Inclusive Framework as "BEPS Associates", it also invited these countries to participate at the level of the CFA on an equal footing. This is accomplished by means of OECD partnerships with non-member countries. The partnership process is described in a 2003 OECD report. ${ }^{21}$ Partnership gives non-members access to CFA and subsidiary bodies, and allows (but does not require) the OECD to recruit staff from any inclusive framework member. ${ }^{22}$

Because the partnership agreements are the official explanation of what particular BEPS Associates agree to when they join an OECD initiative like the Inclusive Framework, these texts are of interest from the perspective of international tax governance but also in terms of international law more generally. Unfortunately, partnership agreements with non-member countries are not publicly available. ${ }^{23}$ Having access to these agreements would potentially shed some light on the question of what

17. See OECD, Who Drives the OECD's Work? (OECD), available at www. oecd.org/about/whodoeswhat/. The OECD membership has changed very little over its lifetime to date. See OECD, List of OECD Member countries - Ratification of the Convention on the OECD (OECD), available at www.oecd.org/about/membersandpartners/list-oecd-membercountries.htm (listing member countries and accession dates).

18. Id.

19. See, for example, J. Braithwaite \& P. Drahos, Global Business Regulation p. 486 (Cambridge U. Press 2000) ("[A]cross the spectrum of regulatory activity, the OECD plays a distinctively important role.").

20. See, for example, Y. Brauner, An International Tax Regime in Crystallization, 56 Tax L. Rev. pp. 259 and 310 (2003); A.J. Cockfield, The Rise of the OECD as Informal 'World Tax Organization' Through National Responses to E-commerce Tax Challenges, 8 Yale J.L. \& Tech. p. 136 (2006); and A. Christians, Hard Law and Soft Law in International Taxation, 25 Wisc. J. Intl. L. p. 325 (2007).

21. OECD, Developing Tax Partnerships: involving non-OECD Economies in the global debate on international taxation (OECD 2003), available at www.oecd.org/tax/administration/30399787.pdf.

22. Communication from OECD staff, notes on file with the author.

23. Some OECD partnerships with other international organizations which are accessible to the public, while presumably not equivalent to its agreements with governments, serve as a reference point. For instance, a 2009 joint statement of the OECD and the European Investment Bank (EIB) is illuminating to the extent it might reflect some typical features of an OECD partnership agreement. See Joint Statement on Co-operation between the Organisation for Economic Cooperation and Development and the European Investment Bank, signed 26 November 2009, available at www.oecd.org/global-relations/oecdpartnershipswithinternationalorganisations/44144089.pdf. In this agreement, the OECD and the EIB lay out their common interests and shared objectives, explain areas of cooperation (for example, research and innovation, cohesion policy, and development policy issues) and means of cooperation (for example, participation in relevant committees and networks, staff meetings and exchanges, and access to OECD statistical research and records). Id., at pp. 2-4. The agreement also explains that the institutions shall exchange information and compare policies while preserving the "statutory rules of confidentiality", although which particular statutory rules might be at play is not explained. Id., at pp. 4-5. 
inclusivity means to the OECD in concrete terms. ${ }^{24}$ In the absence of this information, the structures and purposes of the various OECD forums which have been joined by non-member countries may be inspected for signs of the organization's growing recognition of the need for inclusivity in its tax governance processes.

\subsection{Modes of expansion to non-members}

Non-member countries have been included in general OECD data gathering and monitoring and, in some cases, controlled expansion, since 1992, with non-members invited to OECD tax policy processes beginning around $1999 .{ }^{25}$ It is difficult to pinpoint the precise reasons for the decision to involve non-members in tax policymaking owing to the overall obscurity surrounding the OECD's institutional structure. ${ }^{26}$ Even so, it is possible to trace a path to the Inclusive Framework starting from an initial effort to impose tax constraints on non-member countries in 1998, and proceeding through a series of potentially more cooperative engagement platforms.

The first step toward inclusivity as an expressed OECD tax policy goal traces to a controversial effort by the organization to create a blacklist of tax havens which briefly contemplated the imposition of sanctions on non-cooperative jurisdictions. ${ }^{27}$ However, after losing the support of the United States following the election of George Bush, the OECD altered course and settled on a more cooperative model, introducing a new network of member and non-member countries called the Forum on Harmful Tax Practices. ${ }^{28}$

24. Further, it is not clear whether a documented commitment to implement BEPS avoids being an international agreement. Even if the texts by their terms are not legally binding, they minimally document a set of expectations countries have agreed to meet - much like the BEPS standards themselves.

25. See, for example, Davis supra n. 3 (describing participation of non-members in OECD work, the accession of Mexico and South Korea, and active outreach to China, India, Brazil, among other countries) and A. Christians, BEPS and the New International Tax Order, 2016-2017, B.Y.U. L. Rev. 1603 (2017) (describing OECD use of forums for tax matters).

26. This obscurity has made it difficult to study the organization in the past. While the OECD has embraced transparency in some important ways vis a vis its tax programmes (such as by opening working documents up to consultation and making meetings available for online observation via webinars), in other ways the institution remains difficult to decipher from the outside.

27. OECD, Harmful Tax Competition: An Emerging Global Issue (OECD 1998) (recommending a set of guidelines and timetables for OECD members to identify, report and eliminate harmful tax practices; introducing a general framework for "coordinated defensive measures" against such practices; and establishing a process through which non-member jurisdictions could associate to the report and its guidelines). The effort was controversial because it appeared to target small non-member jurisdictions while ignoring the practices of OECD members that appeared to some to be equally harmful. For a review of these events and the cooperative consensus that emerged, see A. Christians, Sovereignty, Taxation and Social Contract, 81 Minn. J. Intl. L. (2009).

28. For a review of the events that led the United States to rescind its support for the project, see M. Webb, Defining the boundaries of legitimate state practice: norms, transnational actors and the OECD's project on harmful tax competition, 11 Rev. Intl. Pol. Econ p. 787 (2004) and Christians supra n. 27. The OECD explains that it "established an international framework" in 1998 by "adopting its Report, "Harmful Tax Competition: An Emerging Global Issue" which "Ministers ... welcomed ... and mandated OECD to pursue the work". It is not clear how an organization creates an institution by adopting a report, but there are no other official explanations regarding the creation of the Forum on Harmful Tax
The OECD explains that the Forum on Harmful Tax Practices is intended to "work directly and where appropriate through other subsidiary bodies" of the CFA to engage in peer-review and eliminate harmful tax practices. ${ }^{29}$ However, there is little detail about the programme of work or the substance of interventions by non-member countries. ${ }^{30}$ Without more detailed information, few conclusions can be drawn about the nature of the Forum and its impact on non-member countries and on OECD institutional learning about the design, desirability, or effectiveness of including non-member countries in its work programmes. ${ }^{31}$ Even so, some insights may be gleaned from the fact that the OECD used the Harmful Tax Practices Forum as a means to develop more connections to non-member countries and to assess revisions or additions to its institutional design and procedures going forward. ${ }^{32}$

The next step toward inclusivity in OECD tax policy work occurred with the formation in 2000 of the Global Forum on Transparency and Exchange of Information for Tax Purposes (the "Global Forum"). ${ }^{33}$ As originally constituted, the Global Forum was a multilateral framework for member and non-member countries to carry out transparency and exchange of information standards. ${ }^{34}$ In 2009, the OECD reconstituted the Global Forum into a "Part II program" after G20 Leaders called for participating jurisdictions to adopt higher standards of transparency and information exchange. ${ }^{35}$ Becoming a Part II

Practices. Nor are there publicly available documents detailing which states were invited to join, how they joined, whether they paid a onetime or annual fee, or how the work of the Forum was conducted.

29. OECD, Towards Global Tax Cooperation: Progress in Identifying and Eliminating Harmful Tax Practices pp. 5-6 (OECD 2000), available at www.oecd.org/ctp/harmful/2090192.pdf. Further, the OECD established three Working Groups within the Forum to review preferential tax regimes and describes these Working Groups and the Forum as having met and worked intensively between November 1999 and May 2000. Id., at p. 10.

30. The Forum is described as meeting "periodically", more than once a year. In March 2017, the Forum met to undertake "its first reviews of preferential regimes of new Inclusive Framework members". OECD, Harmful Tax Practices - 2017 Progress Report on Preferential Regimes: Inclusive Framework on BEPS: Action 5, OECD/G20 Base Erosion and Profit Shifting Project (OECD 2017), available at http://dx.doi. org/10.1787/9789264283954-en.

31. J.M. Weiner \& H.J. Ault, The OECD's report on harmful tax competition, Natl. Tax J. pp. 601-608 (Sept. 1998) (describing the Forum as "the first broadly mandated international institutional structure directly responsible for the evaluation and coordination of existing and proposed tax measures.").

32. See, for example, Action Plan 5 (committing the Forum on Harmful Tax Practices to "[r] evamp the work on harmful tax practices with a priority on improving transparency" and to "engage with non-OECD members on the basis of the existing framework and consider revisions or additions to the existing framework."). See OECD, Countering Harmful Tax Practices More Effectively, Taking into Account Transparency and Substance, OECD/G20 Base Erosion and Profit Shifting Project (OECD 2014), available at http://dx.doi.org/10.1787/9789264218970-en (tasking the Forum with three outputs, including "consideration of revisions or additions to the existing framework").

33. See OECD, Global Forum on Transparency and Exchange of Information for Tax Purposes (OECD), available www.oecd.org/tax/transparency/.

34. Id. "The original members of the Global Forum consisted of OECD countries and jurisdictions that had agreed to implement transparency and exchange of information for tax purposes."). See also OECD Council (15 Nov. 2012), C(2012)148.

35. OECD, Decision of the Council Establishing The Global Forum on Transparency and Exchange of Information For Tax Purposes, C(2009)122/ FINAL (OECD 2009) [hereinafter: the "2009 Council Decision"], avail- 
program transformed the Global Forum into a "consensus based organisation where all members are on an equal footing ${ }^{36}{ }^{36}$ Membership in the Global Forum is open to all jurisdictions willing to implement the OECD standard on transparency and exchange of information, participate and contribute to the peer review process, and contribute to the budget. ${ }^{37}$ This model is repeated in other forums and the Inclusive Framework.

In reconstructing the Global Forum, the OECD established a steering group and a peer review group, as well as a "dedicated self-standing secretariat based in the Organisation's Centre for Tax Policy and Administration". ${ }^{38}$ It authorized the OECD Secretary General to appoint staff from member countries. ${ }^{39}$ Global Forum jurisdictions are "expected to act on any recommendations in the review and to report back to the Global Forum on actions taken". ${ }^{40}$ The Global Forum currently counts 147 countries as members. ${ }^{41}$ However, there is no public information available about how agenda-setting or procedures for participation and discourse developed for this or any of the other Global Forum meetings. As is the case for the Forum on Harmful Tax Practices, the criteria of inclusivity remain difficult to assess.

The OECD's Global Forums on Transfer Pricing and on VAT represent additional moves toward inclusivity. The Global Forum on Transfer Pricing was convened to create soft law on transfer pricing. ${ }^{42}$ Delegates agreed that during the coming year this Global Forum would carry out a transfer pricing risk assessment, developing a detailed "how-to" manual to establish good practices for governments when they assess transfer pricing risk at the beginning of an audit. ${ }^{43}$ Publicly available documents do not reveal how the designated set of countries was appointed

able at www.oecd.org/tax/transparency/about-the-global-forum/ council-decision-2009.pdf. The "Part II" designation refers to the program's status in OECD budgetary terms. OECD, Member Countries Budget Contributions for 2017 (OECD), available at www.oecd.org/ about/budget/member-countries-budget-contributions.htm ("Part II budgets ... cover programmes that are of interest to a limited number of members and are funded according to scales of contributions or other agreements among the participating countries.").

36. OECD, About the Global Forum (OECD), available at www.oecd.org/ tax/transparency/abouttheglobalforum.htm.

37. OECD, Global Forum on Transparency and Exchange of Information for Tax Purposes, "Exchange of Information on Request, Handbook For Peer Reviews 2016-2020", 3rd edn., p. 5 (OECD).

38. OECD, 2009 Council Decision, supra n. 35, at p. 10

39. Id.

40. Id.

41. It last met in November 2017, when 186 delegates from 78 jurisdictions and 12 international organizations and regional groups came together in Yaoundé, Cameroon. See www.oecd.org/tax/transparency/statement-of-outcomes-yaounde.pdf.

42. Its first meeting was held on 28 March 2012 with tax officials from 90 countries; later meetings swelled to 110 countries and linked with a meeting of the "OECD Task Force on Tax and Development", which is described as "a multi-stakeholder platform." See OECD, Global Forum on Transfer Pricing (OECD), available at www.oecd.org/tax/transfer-pricing/global-forum-transfer-pricing.htm. The 2012 meeting describes the officials as having agreed on the need to simplify transfer pricing rules, strengthen the guidelines on intangible issues and improve the efficiency of dispute resolution. OECD, Tax: OECD to simplify transfer pricing rules (OECD), available at www.oecd.org/news room/taxoecdtosimplifytransferpricingrules.htm.

43. The Forum subsequently met three more times, with the latest meeting held in Paris in 2015. See OECD, supra n. 42. to work out terms, what decision-making processes they employ and how they go about their work.

The Global Forum on VAT is "aimed at senior tax officials and representatives of international organisations, and participation is upon invitation only". ${ }^{44}$ As is the case for the other Forums, the OECD has not made publicly available the process by which countries are invited to participate and on what basis and terms and how member and non-member countries participate in discussions and decision-making. These details are important to assess the work programme of the OECD and its progress toward the goal of inclusivity on an equal footing.

Finally, inclusivity in OECD tax policy work advanced when the organization formed the "Forum on Tax Administration MAP Forum" (the "FTA MAP Forum") in 2013 to deliberate on matters affecting participants' mutual agreement provision programmes. ${ }^{45}$ The OECD describes the FTA MAP Forum as:

a subsidiary body of the OECD Committee on Fiscal Affairs [that] brings together Commissioners from 46 countries to develop on an equal footing a global response to tax administration issues in a collaborative fashion. ${ }^{46}$

As with the other Forums, institutional and procedural details are not made public.

Finally, and much like the Forums before it, the Inclusive Framework is an intergovernmental network formally organized for a specific and limited purpose, namely, to implement the BEPS package with the participation of all interested countries. ${ }^{47}$ After conducting consultations

44. OECD, First meeting of the OECD Global Forum on VAT (OECD) (undated web page), available at www.oecd.org/ctp/consumption/firstmeeting-vat-global-forum.htm.

45. The OECD formed the Forum on Tax Administration in 2002 and the Forum created the FTA MAP Forum in 2013. Forum on Tax Admin., FTA Work Programme 2013/14 (OECD) available at https://www.oecd. org/site/ctpfta/ftaworkprogramme201213.htm. See also Forum on Tax Admin., Multilateral Strategic Plan on Mutual Agreement Procedures: A Vision for Continuous Map Improvement (oecd), available at www.oecd. org/site/ctpfta/map-strategic-plan.pdf ("The Forum on Tax Administration has determined that competent authorities from among the FTA-member countries shall form a forum (the FTA MAP Forum) to meet regularly to deliberate on general matters affecting all participants' programs for conducting mutual agreement procedures."). This redundantly named body had forty-six members when the initial BEPS reports were issued. Action Plan 14 at 16 ("In light of the objectives of the FTA MAP Forum - and, in particular, in view of the role of the FTA MAP Forum in monitoring the implementation of the minimum standard set out in this Report ... countries should become members of the FTA MAP Forum and participate fully in its work.").

46. OECD, Multilateral Strategic Plan para. 5 (OECD).

47. See OECD, First meeting of the new inclusive framework to tackle Base Erosion and Profit Shifting marks a new era in international tax co-operation (OECD), available at www.oecd.org/ctp/first-meeting-of-thenew-inclusive-framework-to-tackle-base-erosion-and-profit-shiftingmarks-a-new-era-in-international-tax-co-operation.htm. This website explains that the OECD set up a steering group comprising twelve of the member countries of the G20 in addition to eight BEPS Associates which decided on procedures for accepting new members to transition on timeline requirements. The task of the steering group was to determine how peer review on the various minimum standards and peer monitoring of related prescriptions would proceed. In addition, the OECD Task Force on Tax and Development Programme announced support initiatives for developing countries seeking to implement or strengthen their regimes for addressing transfer pricing and other BEPS-related issues, through two-to-three year-long capacity development programmes. The Task Force convened a series of regional 
and a survey, the OECD observed in 2014 that many countries lack the capacity necessary to implement the BEPS package, as well as facing inordinate competitive pressure to use the tax system to increase inbound investment. ${ }^{48}$ Acknowledging that these logistical and political challenges to tax cooperation pose distinct problems for differently situated countries, the OECD's answer is to "assist developing countries meet the challenges posed by BEPS, particularly the priorities identified in the Action Plan". ${ }^{49}$ An additional plank is to provide lower income countries with extra time to implement the various action plans (deferred implementation). ${ }^{50}$

At the same time, a major part of the BEPS framework is the gathering of information to measure and monitor the scope and depth of tax avoidance, a phenomenon that appears unlikely to have an end-point. ${ }^{51}$ The Inclusive Framework is, therefore, an open-ended institution that serves as the template for, if not the final structure of, a world tax organization. In this context, participation on equal footing does not just concern implementation issues surrounding a current set of standards, but it also creates the possibility for participation in agenda setting and negotiations on future standards to be developed through its own iterative process.

meetings in 2014 to explain the BEPS initiative and invite non-member countries to join the Inclusive Framework.

48. OECD, Part 1 of a Report to G20 Development Working Group on the Impact of BEPS in Low Income Countries (OECD 2014), available at www. oecd.org/tax/part-1-of-report-to-g20-dwg-on-the-impact-of-beps-inlow-income-countries.pdf.

49. OECD, Part 2 of a Report to G20 Development Working Group on the Impact of BEPS in Low Income Countries (OECD 2014), available at www. oecd.org/g20/topics/taxation/part-2-of-report-to-g20-dwg-on-the-im pact-of-beps-in-low-income-countries.pdf

50. Deferred timelines for non-member countries are referenced but not well explained in OECD, Inclusive Framework on BEPS: Progress Report p. 24 (OECD 2017), available at www.oecd.org/tax/beps/beps-inclusiveframework-progress-report-june-2016-july-2017.htm ("details of the schedules of the peer reviews for each minimum standard can be found in Annex $\mathrm{C}$, including on the mechanism for deferral of a peer review in certain cases to take into account the lower capacity and limited resources of some jurisdictions"). The referenced Annex lavs out timelines for the various action items but does not explain the criteria or process for obtaining deferral, nor does it describe the length of deferral available. An OECD Report on Peer Review for Action 5 explains that "developing countries which requested an additional year to implement the transparency framework will be first reviewed in 2019". See OECD, Harmful Tax Practices Peer Review Reports on the Exchange of Information on Tax Rulings p. 10 (OECD 2017). Similarly, an implementation schedule for Action 14 lists countries for which deferred peer review is in place. See OECD, Assessment Schedule for Stage 1 Peer Reviews (OECD), available at www.oecd.org/tax/beps/beps-action-14peer-review-assessment-schedule.pdf. See also OECD, BEPS Action 14 on More Effective Dispute Resolution Mechanisms p. 20 (OECD 2016) (providing circumstances under which "the MAP Forum should defer the review of any such member that is a developing country and is not an OECD or G20 country"). It would be helpful if the OECD would provide information explaining the expectations placed upon various jurisdictions. Without such information, suspicions might arise that some countries could be unduly advantaged, and others unduly disadvantaged, by undisclosed and potentially negotiable implementation timelines.

51. See OECD, Transfer Pricing Documentation and Country-by-Country Reporting, Action 13 - 2015 Final Report (OECD 2015), available at www.oecd-ilibrary.org/taxation/transfer-pricing-documentationand-country-by-country-reporting-action-13-2015-final-report_978 9264241480-en

\section{Defining and Assessing Inclusivity}

Without access to documents outlining the purposes, agreements, structure, agenda-setting, negotiation and other processes of the OECD's various Forums, leading up to and including the Inclusive Framework, it is difficult to make judgements about how the OECD defines inclusivity. The Organization's relatively opaque institutional hierarchy prevents a full assessment of exactly how non-member states participate in OECD projects, on what terms, to what ends, and with what consequences. It can reasonably be expected that questions will arise regarding the meaning of equal footing given the vastly unequal means of non-OECD countries to participate in international negotiations.

As a threshold matter, defining inclusivity on an equal footing would seem to require setting expectations regarding the scope of participation, because of the potentially vast difference in resources available to OECD and nonOECD countries. For example, if equal footing entails all participating states sending qualified representatives to regular meetings of working parties, the fundamental inequality of resources among nations arises as a key issue. Resources are at issue in relatively straightforward logistical terms, such as in decisions to divert individuals from regular tasks to undertake travel, as well as in terms of funding the travel itself. But resources are also at issue in confronting a more difficult problem, namely, deciding what if anything the OECD should do if some countries do not have personnel that are qualified to engage in international negotiations on taxation.

This issue has been observed as important in the trade context, where ensuring the presence of qualified representatives at formal meetings has been identified as a barrier to participation..$^{52}$ Observers of World Trade Organization (WTO) processes have responded by seeking travel subsidies and technical assistance for delegations from lower income countries, but critics maintain that these efforts cannot overcome the challenges. ${ }^{53}$ The OECD will likely

52. S. Ostry, Asymmetry in the Uruguay Round and in the Doha Round, in Developing Countries in the WTO Legal System (C. Thomas \& J.P. Trachtman eds., Oxford U. Press 2009) (noting that "[t]here was very little participation by the African countries in the Uruguay Round because of both the lack of personnel in Geneva delegations and the lack of coordination and expertise at home. ...There is still serious weakness in domestic coordination mechanisms among a number of ministries; this institutional deficiency is not confined to the poorest countries but affects many developing and transition economies as well. Finally, there is little, if any, coordination between Geneva and the home country. A former delegate noted, '(d)uring the entire duration of the Uruguay Round our Geneva-based WTO team received two instructions from our capital'."). See also D. Moellendorf, The World Trade Organization and Egalitarian Justice, 36 Metaphilosophy pp. 145 and 154 (2005); Caney, supra n. 7, pp. 725 and 746 (2006) (discussing the problem of ensuring adequate representation at meetings); and R. Blackhurst, B. Lyakurwa \& A. Oyejide, Options for Improving Africa's Participation in the WTO, 23 World Econ. pp. 491 and 494 (2000) (observing that many delegations experienced being "overwhelmed by the complexity of the negotiations and the technical nature of many issues being discussed and/or negotiated").

53. S.P. Shukla, From the GATT to the WTO and Beyond, in Governing Globalization pp. 254-286 (D. Nayyar ed., Oxford U. Press); Moellendorf, supra n. 52, at p. 154; Caney, supra n. 7, at p. 746; G. Shaffer, Can WTO Technical Assistance and Capacity-Building Serve Developing Countries?, in Reforming the World Trading System: Legitimacy, Efficiency, and Dem- 
face similar problems and requests to provide requisite resources. ${ }^{54} \mathrm{~A}$ realistic response is needed if inclusivity on an equal footing is to be more than an aspirational ideal.

Comments from OECD secretariat and OECD documentation reveal that these problems are understood to be relevant and difficult to overcome. For instance, the OECD is working on specialized programmes to support countries in sending officials to meetings, as part of an overall process of facilitating engagement with lower-income countries. ${ }^{55}$ However, it is well understood within and outside the OECD that getting qualified personnel to meetings may be hampered not only by immediate resource constraints but also by the constant need for specialized training and the high turnover created when government personnel receive such training and then become attractive to private firms. ${ }^{56}$ If participating on an equal footing is the key to getting priority tax policy concerns addressed in a systemic way, securing participation by qualified and knowledgeable personnel becomes paramount. ${ }^{57}$ Without a strategy to achieve this difficult

ocratic Governance (E.U. Petersmann \& J. Harrison, eds., Oxford U. Press 2005); K. Nicolaidis \& G.C. Shaffer, Transnational Mutual Rec ognition Regimes: Governance without Global Government, 68 L. \& Contemporary Problems pp. 263-318 (2005); and G.C. Shaffer, Transnational Legal Ordering and State Change (Cambridge U. Press 2013).

54. Some of these issues have already been raised. For example, Sengupta objects that for non-member countries the benefit of the Inclusive Framework is limited to participation in OECD meetings "to put their stamp of approval on what has already been agreed upon”. See D.P. Sengupta, BEPS on an unequal footing- be on your guard!, taxindiainternational.com (28 July 2016). Sengupta notes that for lower income countries, the cost of participation is high both in terms of finding experienced staff and financing member fees and travel. He concludes that participation on an equal footing requires preparation "financially and otherwise in all the numerous meetings of different working parties that take place almost ceaselessly", a virtually impossible task for many lower-income countries

55. See OECD, Developing countries and BEPS (OECD), available at www oecd.org/tax/developing-countries-and-beps.htm.

56. This problem is well known across the world as the revolving-door problem. See, for example, R.H. Mundheim, Conflict of Interest and the Former Government Employee: Rethinking the Revolving Door, 14 Creighton L. Rev. p. 707 (1980-1981) and L. Seabrooke \& D. Wigan, Pow ering ideas through expertise: professionals in global tax battles, $23 \mathrm{~J}$. Eur. Pub. Policy 3, pp. 357-374 (2016). See also L. Seabrooke \& E. Tsingou, Distinctions, affiliations, and professional knowledge in financial reform expert groups, 21 J. Eur. Pub. Policy, p. 389 (2014). A relationship between government and the private sector, including flow of personnel, is not a solely negative phenomenon but may, in ideal circumstances, carry positive spillovers such as knowledge transfer from the private sector to the government. However, when the personnel flow is exclusively from government to the private sector, governments may be disadvantaged by asymmetrical information. This is a difficult problem in all areas of regulation and governance that must be factored in as a significant capacity constraint when designing an international regulatory or policy-making body.

57. This raises the perennial difficulty of unequal bargaining power in negotiations. In the context of trade negotiations Stiglitz and Charlton (2005) warn that while increased transparency and technical assistance may put parties on a more equal footing, "advanced industrial countries are still able to get their way, particularly by withholding aid unless developing countries accept their demands". See J. Stiglitz \& A. Charlton, Fair Trade for All: How Trade Can Promote Development (Oxford U. Press, 2005), p. 75. Since inequalities in bargaining power are mostly the result of material economic inequality, there are no easy fixes. See for example, Ostry, supra n. 52, at p. 106 ("ii]deally, the playing field should have been leveled as poorer states had as much legal authority as the more powerful states. Did this increased legalization of the system offset asymmetry? Not exactly, alas"). Ostry, supra n. 52 concludes that "the new legal order has not affected the poorest countries. It is not possible to get data on a number of legal experts in their Geneva missions or their domestic ministries. One can safely assume that the numbers task, the Inclusive Framework risks continuing the status quo in which "standards developed by a limited number of countries can get the status of international ones". ${ }^{58}$

The issues raised by these structural background conditions are not limited to international tax governance; they permeate all questions of international relations. This is clear even to philosophers who deny the global scope of egalitarian distributive justice. For instance, Miller (2007) notes that the material inequalities "will naturally translate into inequalities of power, which then become a source of ongoing global injustice", where the injustice is not the distributive inequality per se, but the inability of the poor to "enjoy an adequate measure of self-determination" ${ }^{59}$ Pogge (2007) goes even further and identifies the possibility of a vicious circle, where material inequality:

enables the rich to shape the global rules in their favour. Such rules allow them to capture a disproportional share of global economic growth. This in turn gives them even greater influence over the global rules and thus allows them to tilt these rules even further for their own benefit. ${ }^{60}$

Despite these inherent governance challenges, the OECD points to some successes, noting that some " 60 developing countries have participated directly or indirectly in the process and shaped the outcomes through regional consultations and thematic global fora" ${ }^{61}$ The OECD explains that it has a "strategy for deepening developing countries' engagement in the BEPS Project", based on three pillars, namely: (1) direct participation of non-member countries in the CFA and its subsidiary bodies; (2) OECD partnership with regional tax organizations and participation in regional conferences; and (3) OECD "capacity building support", which includes work with the G20 Development Working Group. ${ }^{62}$

Based on this commitment and the core rationale of inclusivity, the OECD should anticipate that building a new global forum for the purpose of implementing a package of rules and standards will only achieve its stated goals with a great deal of attention to key governance issues. ${ }^{63}$ Ultimately, the OECD will have to reconcile its essential nature as a member organization operating under

are very small or even nonexistent. One reason is very clear and simple - lack of money. The absence of government legal services either at home or in Geneva would require hiring lawyers, which is far too expensive." Id.

58. See Ostry, supra n. 52

59. Miller, supra n. 10 , at pp. 75-76

60. T. Pogge, Why Inequality Matters, in Global Inequality pp. 132-147, at p. 138 (D. Held \& A. Kaya eds., Oxford U. Press 2007).

61. See OECD, Developing countries and BEPS, supra n. 55.

62. Id. The G20 Development Working Group is an intergovernmental network established to implement the 2009 G20 Framework for Strong, Sustainable and Balanced Growth. See G20, Development Working Group Information Exchange Facility (G20 2009).

63. See, for example, T. Ryding, Briefing - OECD announcement about the new "Inclusive Framework" eurodad (27 Feb. 2016), available at www. eurodad.org/OECD_inclusive_framework. ("The good news is that the OECD governments have in principle admitted that the global tax system is broken, and that developing countries have the right to a seat at the table governments negotiate how to fix it. But they still don't walk the talk. We still need a global tax process where developing countries are not always forced to follow the agenda of the OECD governments, and where more ambitious proposals for reforming the global tax system can be put on the table. The only place that can offer this is the United Nations."). 
an exclusively member-driven hierarchy with its stated goal of achieving inclusivity on an equal footing among member and non-member states. The lesson from other global governance efforts is that being clear about its institutions and processes is fundamental to the exercise, even if no guarantor of success.

\section{Conclusion}

The Inclusive Framework continues the OECD's expansion of tax cooperation beyond its member countries, but it unfortunately also continues an OECD tradition of institutional and procedural opacity. As such its emphasis on inclusivity is intuitively appealing but elusive. The question for non-member states is whether, in the long term, the Inclusive Framework can adequately define and then deliver on the promise of inclusivity on an equal footing. Since it is not possible to experiment without significant costs, the decision to move forward with the Inclusive Framework is fundamentally an act of trust in the OECD as an institution. However, better assessment of the likely costs and benefits of participation could be achieved with greater transparency from the OECD as well as the governments that are or seek to be affiliated with it.

In the absence of greater institutional transparency, the risk that inclusivity will be dismissed as political rhetoric seems unnecessarily high. This would be unfortunate because there is strong theoretical support for inclusivity as a general policy goal. Drawing lessons from other areas of global governance, it is both normatively justified and pragmatically wise for the OECD to respond to foreseeable challenges and critiques by significantly increasing the visibility of its institutional design and decision-making procedures.

\section{育}

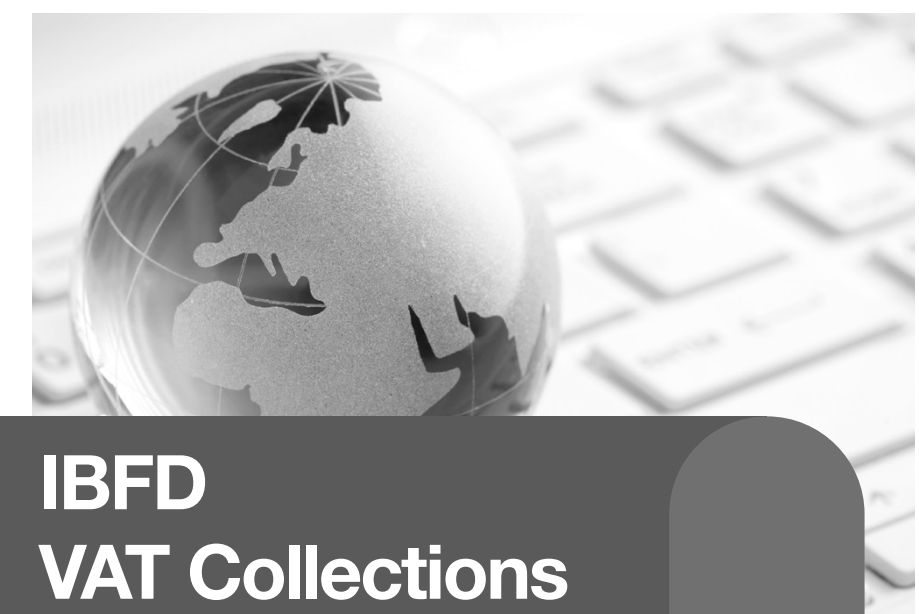

One source for VAT specialists
Continually expanding and updating our VAT collections, we are covering more and more countries and tax systems. Our VAT Collections provide:

- Worldwide coverage of VAT and sales tax systems

- The possibility to compare tax rules in our Historical Tax Archives, dating back to 2009

- A fully integrated resource database with cross-references between news, rate tables, commentaries, practical journal articles, domestic laws, EU VAT Directives, domestic and ECJ case law

- Access anywhere anytime via the online IBFD Tax Research Platform or from your mobile via m.ibfd.org

To see the full content and tools of our VAT collections, take a free 7-day trial. For more information or to order, please visit www.ibfd.org.

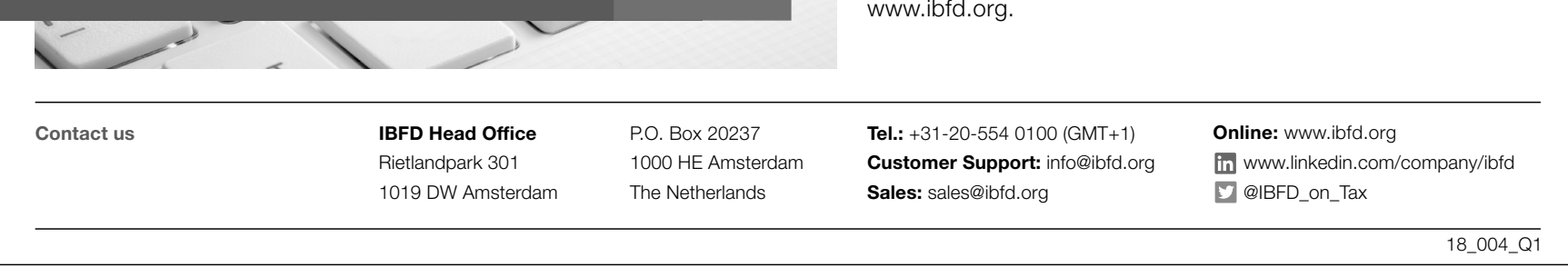

